\title{
Open Innovation Practice: A Case Study of University Spin-Offs
}

\section{Yuliya Shutyak}

\begin{abstract}
The paper investigates the practice of Open Innovation (OI) of university spin-offs. Three interviews were conducted to discuss the knowledge of spin-offs about Ol, their attitude to this innovation management strategy based on perceived advantages and disadvantages, and their motivation towards OI practice in the future. Problems with planning, control and trust appear to be some of the most important for Ol success. Focusing on these and other urgent aspects of $\mathrm{Ol}$, the article discusses a research agenda that can help in formulating research questions and hypothesis, thus directing their efforts to search for solutions to identified problems.
\end{abstract}

Keywords: innovation, open innovation, spin-off, small and medium business.

\section{INTRODUCTION}

The phenomena of Open Innovation (OI) have been known for decades. However, the popularity of $\mathrm{OI}$ has been growing among both practitioners and business researchers since comparatively recent times (Chesbrough, 2003; West, Vanhaverbeke, \& Chesbrough, 2006). In 2010, Gassmann, Enkel, and Chesbrough (2010) announced the beginning of the era of OI (p. 214) by stating "a small community of management researchers has recently developed into an established research field" (Gassmann et al., 2010, p. 212). Immediately, it turned into "one of the hottest topics in innovation management" (Huizingh, 2011).

Ol "assumes that firms can and should use external ideas as well as internal ideas, and internal and external paths to market, as the firms look to advance their technology" (Chesbrough, Vanhaverbeke \& West, 2006, p. xxiv). Indeed, the external sources of knowledge and resources are admitted to be important for the innovative activity of an organization. Internal R\&D activity, especially for firms with limited resources, becomes less effective (Brunswicker \& Ehrenmann, 2013). More and more often, innovations appear

1 Yuliya Shutyak, PhD., University of Liege, HEC Management School, CEPE, 14 Louvrex str., Liege 4000, Belgium. E-mail: julx@ua.fm. 
as a result of the functioning of inter-organizational networks, when a firm's openness allows the knowledge, specialism, and innovations of other firms to be accessed.

Examples of OI can be found in businesses of different sizes. However, small and medium enterprises (SMEs) are considered to be more inclined to openness in their innovative activity due to them having less resources available for in-house innovations in comparison with large enterprises (Brunswicker \& Ehrenmann, 2013; Spithoven, Vanhaverbeke, \& Roijakkers, 2013). This is also true for university spin-offs that are small or medium by their size in many cases, at least in the first stages of their development. Even more, they are born through innovative activity (Druilhe \& Garnsey, 2004) being products of OI ( Chesbrough et al., 2006). Therefore, they are supposed to be more open in R\&D.

Despite such specifics of spin-offs, little research is done on their practice of Ol. Thus, Walter et al. (2011) focus more on innovation success of university spin-offs rather than precisely on OI. Some other research papers are devoted mainly to the performance issues of innovative activity of firms, ignoring other important aspects. Perkmann and Walsh (2007), studying universityindustry relations and $\mathrm{Ol}$, point to the need to explore further other aspects of OI such as incentives and motivation, OI strategies, types of innovative activity, etc. Alternatively, literature on $\mathrm{OI}$ at SMEs offers additional insights but still remains limited in number and geographical scope. With regard to that, this research is to contribute to a scarce literature on the practice of $\mathrm{OI}$ of university spin-offs and suggest additional research directions based on the obtained results. The following part of the paper proposes a brief overview of academic literature which allows this research to be more focused. It gives a methodological basis for preparing and conducting interviews with spin-offs. The final parts include a discussion on the interview results and suggestions for future research.

\section{LITERATURE REIVEW}

The OI paradigm expands the so-called traditional Closed Innovation model by adding the necessity of combining internally and externally developed technologies to create business value (Chesbrough, 2003). In that sense, companies do not need to rely solely on their internal capacity, but they may include external human, financial and natural capital to manage their innovation processes and its commercialization. This approach quickly captured the attention of the academic world, and today the topic of OI practice is widely covered in literature, where many authors agree that $\mathrm{OI}$ has a much broader application than first proposed by Henry Chesbrough. 
Authors debate the Ol concept, especially its definition and nature (Elmquist, Fredberg, \& Ollila, 2009). Despite some differences of opinion, researchers agree on the main distinguishing feature of OI. Namely, while Closed Innovation relies on internal knowledge, Ol admits the importance of both external and internal sources of innovation. In Ol discourse, Chesbrough (2006) speaks about "the use of purposive inflows and outflows of knowledge to accelerate internal innovation, and expand the markets for external use of innovation" (p.vii). West and Gallagher (2006) discuss the use of "a wide range of internal and external sources for innovation opportunities" (p. 320). While Sisodiya, Johnson, and Grégoire (2013) perceive Ol with its inbound element which involves "... the systematic practice of integrating external inputs into a firm's extant new product technologies" (p. 2).

Further, the $\mathrm{Ol}$ model seeks the commercialization of R\&D results (Chesbrough et al., 2006). For this purpose, firms use various ways to market that manifest themselves in different forms of OI practice. Petroni, Venturini, and Verbano (2012), based on literature review, list several practices of OI among companies such as R\&D outsourcing and alliances with private and public research centres; external stakeholders involvement (joint ventures, strategic collaboration on specific issues), licensing of other firms' IP; recourse to small but highly specialized research firms, participation in technology transfer programs and programs of public procurement. Those authors own empirical research supplements above strategies for increasing openness in innovation processes, with such practices as acquisition of research firm with specialized knowledge, doubling contract with different research institutions, wide-ranging participation in precompetitive research, cooperation in research and experimentation with suppliers and customers, financing academic research programmes, use of networks of technology brokering, contracting consultants, organization of innovation conferences and seminars.

Each of the forms of OI constitutes a separate thread of research in the academic literature, along with such topics as OI strategy and organization design (Biondi, Calabrese, Capece, Costa, \& Di Pillo, 2013), role and model of leadership (Lindegaard, 2010), culture (Herzog, 2011), technology (Wild \& Griggs, 2008), opportunities and barriers (Chesbrough, 2010). At the same time, a lot of questions remain underexplored, among which is the practice of Ol of university spin-offs.

The most common and "natural" innovation centres are universities. They are admitted as important players in research creation and knowledge dissemination within the academic community. Apart from that, they educate and qualify personnel for industry thus contributing to technology transfer (Gunasekara, 2006). However, in the last decade, there has been a growing 
need for universities to disseminate their research and knowledge beyond the academic community. Successful university spin-offs such as Google and Genentech have applied even more pressure. As a result, many universities actively try to convert new scientific discoveries into spin-off ventures (Arvanitis, Kubli, \& Woerter, 2008; Perkmann \& Walsh, 2007; Steffensen, Rogers \& Speakman, 2000).

A university spin-off is an endeavour set up by academic entrepreneurs based on intellectual property generated through their research (Shane, 2004). "University spin-off companies are outputs of university research related activity and an outcome of the university's purposive technology transfer efforts" (Link \& Scott, 2005). They are seen as tools for transferring knowledge between research facilities and companies (Wennberg, Wiklund \& Wright, 2011) especially in area of new products, new processes or new services. Pirnay, Surlemont, \& Nlemvo (2003) define a university spin-off as a particular type of young high-tech firm, created for the purpose of knowledge, technology or research results commercialization developed within a university.

Simultaneously, spin-offs are considered as products of Ol practice (Chesbrough et al., 2006). Such an origin may lead to a suggestion that spin-offs are inclined to Ol more than other businesses. There are two main reasons for this. First, spin-offs do not emerge as any usual enterprise. They are born by an existing organization and may keep connections and implement various projects in cooperation with a parent organization during all of the following years, and even more, build additional contacts with other research centres and universities. Second, the size of spin-offs may play a crucial role in choosing a model of innovativeness. Speaking about university spin-offs, many of them are created as small or medium organizations and, consequently, possess the advantages and disadvantages of SMEs.

These two factors may lead to different OI practice in spin-offs compared to other firms. However, a handful of studies analyse OI practices in university spin-offs. Perkman and Walsh (2007) enumerate several university-industry links like collaborative R\&D, contract research and consulting, development and commercialization of technologies pursued by academic inventors through a company they (partly) own, training of industry employees, informal and formal social relationships and networks at conferences, scientific publications used within industry.

All these studies are important to understand the practice of OI among university spin-offs. At the same time, most of them use the definition of OI proposed by Henry Chesbrough in 2003 or its derivatives, which is criticized for being too wide to be appropriate for different types of enterprises. A similar situation is observed in the case of SMEs. Small businesses admitted 
to being an important source of innovations (Brunswicker \& Ehrenmann, 2013; Spithoven et al., 2013) but the definition of Ol in SMEs remains under discussion. Definitions used in most research on both large and small businesses do not always distinguish particular qualities of SMEs.

Gianiodis, Ellis, \& Secchi (2010) summarise the important elements of conceptualization of OI that include inflows and outflows of knowledge, firm boundaries and their permeability, a firm's deliberate adoption practices, and factors that influence success or failure of OI (p. 4). With regard to small business, particularly the last three elements seem to distinguish SMEs from large enterprises. First, SMEs are considered more open in innovation activity, particularly, if these SMEs are university spin-offs.

Another distinguishing feature is adoption practice which varies from one enterprise to another. Thus, when spin-offs are assumed to be already open to OI due to their origin, other SMEs may still need to implement OI. With regard to such enterprises, Brunswicker \& Ehrenmann, (2013) characterise open innovation search by SMEs as purposive and non-pecuniary. Among factors that influence the adoption of $\mathrm{OI}$, researchers point to less formalised internal R\&D practice, different characteristics of formal and informal networks (Spithoven et al., 2013), a focused business portfolio and specialized knowledge base (Bianchi, Campodall'Orto, Frattini \& Vercesi, 2010). Lee, Park, Yoon, \& Park (2010) make a case for emphasizing the commercialization stage in the Ol efforts of SMEs, due to a lack of manufacturing capacity and access to the innovation market.

Finally, smallness creates a specific for SMEs barriers and motivators to OI: small businesses being more flexible and less bureaucratic are ideal cradles for innovations but they also lack resources that can constrain innovative activity or serve as a driver to search for external sources of innovations (Spithoven et al., 2013). Some studies particularly focus on these and other barriers and motivators to OI among SMEs (van de Vrande, de Jong, Vanhaverbeke \& de Rochemont, 2009), including spin-offs (van Geenhuizen \& Soetanto, 2009). Among the benefits, scientific literature discusses the reduction of cost and time or access to additional resources and facilities, faster knowledge dissemination, access to different kinds of knowledge, shortening of timeto-market, learning new skills and some others (Arvanitis et al., 2008; Van Geenhuizen \& Soetanto, 2012). Among the obstacles of implementing OI models in university spin-offs, researchers point to a lack of transparency; high level of informality; deficiencies of the companies; different interests and attitudes to research; lack of confidence in the business world and the risk of damaging scientific reputation; endangering scientific independence and neglect of basic research; lack of human resources for knowledge and technology transfer (Arvanitis et al., 2008; Van Geenhuizen \& Soetanto, 2012). 
The findings of previous research create an impression of the overall culture of $\mathrm{OI}$ among SMEs and in many cases present $\mathrm{Ol}$ as a key to the success of enterprises. Notwithstanding the importance of the previous research, this prevalent vision of $\mathrm{OI}$ in spin-offs and other types of SMEs needs to be questioned. Some researchers take it for granted, in spite of the fact that $\mathrm{OI}$ is a relatively new topic in research literature and, with regard to SMEs, still does not have a generally accepted clear narrow definition. This concern relates particularly to the vision of the prevailing openness of small and medium business entities, including university spin-offs, and the deliberate practice of $\mathrm{Ol}$ in such enterprises.

Moreover, the study of Ol practices among university spin-offs and SMEs remain limited in number and geographical scope. Some additional exploration would make a contribution in several ways. First, new cases would increase the number of explored cases thus strengthening or questioning the reliability of previous research (Gassmann et al., 2010; Spithoven et al., 2013). Second, new insights may emerge revealing additional directions for future research. This is particularly important when the previous research was based on too narrow a conceptual framework, limiting the scope of attention. Therefore, in this study, we would like to question several dominating views. We will question an overall culture of $\mathrm{Ol}$ among spin-offs by exploring during several interviews what spin-offs know about $\mathrm{Ol}$ and how they correlate OI with innovation practice at their organizations? Second, we will explore what managers think about $\mathrm{OI}$ in terms of success and failure and factors that led to such a result in their organizations?

\section{RESEARCH METHODS}

\section{Multiple case study: Selection of cases}

To explore the practice of Ol of university spin-offs, we use case study as our main research strategy.

First, letters were sent to spin-offs of the University of Liege (Belgium) that included an explanation of the research purpose and research design and an invitation to participate in an interview for this research. The spin-offs were selected based on our knowledge of them rather than by any other criterion. We received three replies with agreement to participate in the research.

All three cases represent small and medium companies that have successful commercialization of their products and services. The spin-off $X$ was established in 2004. It specializes in the field of structural dynamics. Its main clients are companies from the aerospace sector (approx. 60\% of clients) 
and mechanical industries. The company proposes solutions, simulations and experimental testing to improve the design and mechanical strength of equipment and structures under vibration; and services for monitoring the vibration of production equipment. During the interview this company was presented by Mr. S., the founder and owner of this enterprise, who also performs the function of Managing Director.

The second case is $Y$. Originating from a research project, the company was established in 1986 as a spin-off of the University of Liege. It specializes in the field of advanced digital data validation and data reconciliation. Nowadays, it has approximately 30 employees. The company also launched an activity in the USA where it has registered a branch. The interview was given by Mr. Ch. who has worked for the company for the last five years as a spokesman to customers, responsible for several aspects of development in the company including the development of products and research activity.

$Z$, the third interviewed spin-off, was established in 1986 and has 80 employees nowadays. The activity of the company, which is now part of Siemens, relates to aerospace ( $80 \%$ of activity). The company develops engineering software. The historical product is $\mathrm{S}^{* * * *} \mathrm{~F}$, Finite Element Metallic and Composite Structures Analysis software, which can be used to support the sizing of aircraft, aero engines, space launchers, satellites, space propulsion, cars, combustion and electrical engines, wind turbines, gas turbines, trains, machine tools, robots, flexible pipes, and many other machines. The interview was organized with $D$. G., responsible for $R \& D$ projects at $Z$ including development of cooperation and participation in regional, European Space Agency and EU projects.

\section{Data collection and data analysis}

A semi-structured interview serves as the main method of data collection. Representatives of three spin-offs of the University of Liege kindly agreed to participate in this research and meet for interviews. Two interviews were face-to-face interviews organized at sites of $Y$ and $X$. The interview with $Z$ was organized by phone. Each interview was approximately 30-40 minutes' duration. Answers were recorded with a Dictaphone. Interview questions included general questions regarding the activity of an organization and a respondent, and more specific questions regarding innovative activity of a spin-off, success stories and failures with regard to Ol, motivators and demotivators for OI practice.

To raise the validity and reliability of research results, analysis of the data obtained from these interviews was conducted through the three-stage 
process recommended by Miles and Huberman (1994). These stages include: data reduction, data display and conclusion drawing.

Data reduction assumes "selecting, focusing, simplifying, abstracting and transforming" (Miles \& Huberman, 1994). First, the recorded conversations were played several times to recall the details of the interviews and to get a deeper understanding of the experience that spin-offs had with OI. Further, each line of a transcription was numbered according to the question number or given a key word. This stage was important so as not to miss information, when an answer on one question may contain answers on some other questions, or additional issues that arose during the interview. Then, the data was grouped by themes to get a general image of answers for each question asked, as well as information about new issues that emerged.

The final results of data reduction and data analysis were sent to all respondents to read, so as to have additional confirmation from them that the interpretation of their words was done correctly.

\section{FINDINGS}

\section{Openness of spin-offs}

Despite the growing popularity of the OI paradigm, only one of three respondents heard about it from a master student who conducted research on OI. Naturally, none of the spin-offs could introduce any formal roadmap for OI on the date of the interview. Simultaneously, when they all speak about the innovativeness of their firms, it becomes obvious that openness is not new for them. Despite the absence of written strategies, openness seems to have a form of "everyone knows it by default" through oral communication and previous experience. As Mr. Ch. $(X)$ confirms, "Openness is a part of our regular operation". Competition in the industry and the size of the firms does not allow them to innovate only internally. Even if they like to be closed, reality pushes them to search for innovative solutions outside of their companies. The Ol model allows for filling the gap in a company's expertise and using resources more effectively (Mr. S. (Y), Mr. Ch. (X), Mr. G. (Z)).

As expected, the practice of $\mathrm{OI}$ in university spin-offs varies and includes both inbound and outbound innovations. Probably, the most common is collaborative R\&D. The way spin-offs find their partners, to a great extent, corresponds to the statement of Perkmann and Walsh (2007) who argue

that "search processes are socially selective in the sense that they are likely to be influenced by existing inter-personal networks and/or previous interorganizational collaboration" (p. 273). Thus, spin-offs tend to continue collaborating with universities and research centres. Being born by such 
centres, spin-offs trust them and already know how such centres function, and how to work with them.

Then, various regional and European programs provide opportunities for small businesses to develop and implement innovative projects in collaboration with other companies and/or research centres. Similarly, regional clusters allow participants to accelerate R\&D through partnerships with companies of different size, research centres and universities. For example, $Z$ strengthens its innovative network by participation in two poles of competitiveness - Skywin for aerospace and Mecatech for mechanical engineering.

Simultaneously, a large portion of innovative activity of the interviewed spin-offs remains in-house. It is ever possible to speak about the absolute openness of spin-offs. "It is not a choice between Open and Closed Innovation, it is a mixture, it is not exclusive" (Mr. G., Z). Moreover, Ol practices and knowledge transfer technology, has a different nature in different industries. This is particularly relevant for those who operate in very competitive industries. Our cases confirm the findings of Meyer-Krahmer and Schmoch (1998), Schartinger, Rammer, and Fröhlich (2006), and Oakey(2013) according to which more intense research collaboration is preferred in more traditional sectors, while the opposite is true for software development.

\section{"If you want something done right, you've got to do it yourself"?}

As discussed above, spin-offs can be considered as more open than other businesses. Indeed, interviewed university spin-offs confirmed that openness is vital for them to continue remaining innovative and develop further. However, using the Ol model does not necessarily mean that all spin-offs tend towards openness. "If you want something that you cannot do, indeed it is better to use external resources to do it, for example, from academia", ascertains Mr. G. (Z). At the same time, the spin-offs prefer to develop and implement innovative projects in-house every time, whenever this is possible. The reason for such a position is not only competition but also a desire to control innovation activity.

The problem of control over desirable results from cooperation with external organizations remains one of the most urgent for many spinoffs. It is possible to distinguish at least two objects that spin-offs seek to control: functionality and quality of a product, process, or method obtained via external sources; and organizational aspects of Ol model. First, the end product, process, method or any other innovative result need to meet certain expectations. Thus, Mr. S. $(Y)$ admits, "We leave little openness. We clearly demand from partners what we want and set desired goals". The 
spin-offs want to control innovation activity, especially, in cases when they have concrete criteria and standards, or when they search to develop new capabilities, new small pieces that need to be integrated in the existing product or process.

Second, control is considered vital in the case of establishing a partnership. "If you do not have control in your hands it may take a long time as you wait for replies from other people" (Mr. Ch., $X$ ). In this case, the spinoffs try to control the organizational processes of Ol; in order to maintain the dynamics of activities; meet deadlines; and decrease the time-to-market.

To resume, although at the earlier stages of concept development OI was considered as the opposite to Closed Innovation (Chesbrough, 2003), several years later the same researchers point out that organizations are not willing to totally abandon the wish to invoke control over others in Ol processes (Chesbrough \& Appleyard, 2007). The "controlled" openness perspective could solve this challenge (Wikhamn, 2013) and the interviewed spin-offs are good examples of it.

\section{Success and failure, motivation and demotivation}

Motivation to openness may vary from one enterprise to another depending on previous experience, industry, and other factors. We observe the same in the case of the interviewed university spin-offs. "We need to open...", admits Mr. S. ( $Y$ ). "We need to open because we are in sector where we need constant evolution...", explains Mr. G. (Z). "However, openness is also not easy", argues Mr. Ch. $(X)$ more sceptically.

The interviewed spin-offs confirmed that they all had both successful and unsuccessful experiences with innovations. Mr. Ch. $(X)$ provided an example of successful collaboration between $X$ and two other companies on the development of one innovative product. He sees several reasons for success of that cooperation. First, the product was a particular request from an end customer. It meant that requirements were defined, every collaborating company had its own piece of work to do, and everyone knew that the product would find its market. Simultaneously, each company kept its image and could approach the market independently of other partners.

The same company also had unsuccessful attempts at innovating with partners. $X$ was considering implementing one innovative idea in cooperation with another company. Both companies found the product potentially interesting. However, as explained by Mr. Ch., this product was not requested by an end customer and market reaction to this product was uncertain. Moreover, each company did not want to share its identity or become dependent on another company. Simultaneously, neither party could 
propose a strategy that would satisfy everyone and allow them to approach the market. As Mr. Ch. resumes, "not only technical, but also commercial aspects behind the business model, could impact everything".

Similar to Mr. Ch. (X), Mr. G. (Z) and Mr. S. (Y), speaking about successful cases of OI, agree that clear goals and a well-defined plan constitute one of the key factors of success. While, poor planning of resources and a lack of clear objectives, led their companies to the failure of some projects.

In addition to that, trust and (un)ethical conduct play a crucial role in the success or failure of common initiatives. $Y$ experienced a situation where the results of several years of cooperation were taken by partners for further commercial use without any compensation to $Y$. The company never met such unethical behaviour in their collaboration with universities and research centres, as Mr. S. explains. IPR management could be a solution. However, it may require additional resources, time, knowledge, and create additional barriers to more open innovative activity.

Some other barriers to $\mathrm{Ol}$ were mentioned during the interviews: difficulty to integrate external innovations into a firm's existing product, process or method; lack of expertise and organizational barriers. Mr. S. (Y) shares, that probably the most serious impediment for OI is "the problem of protocols, connections, and compilation of results". Those bricks that the spin-off finds outside the company need to be integrated in such a way that the company achieves the desired results. It may require internal and/ or external expertise, additional development and testing. If something is missing, the firm needs to begin searching again for the "missing bricks". All these processes may lead to considerable time and resource investments.

Further, a lack of external expertise forces some spin-offs to implement some projects internally. Despite the widely acknowledged fact that not all smart people are working inside the firm, reaching those external experts and their knowledge is not always possible. Expertise can be missing in other companies and also those research centres and universities that prohibit $R \& D$ in a certain direction.

Finally, organization of the OI model, especially, when the firm searches to have "controlled" openness, can be a problem. As the spin-offs admit, some regional and European programs provide an opportunity to expand the external network of experts and potential partners, suppliers and customers. Simultaneously, organizational aspects such as preparation of documents, organization of meetings, follow-up of initiatives, etc., require not only responsible persons but more enthusiastic persons, who will believe and who are passionate about what they do. As the interviewees argue, a lack of internal resources cannot be substituted by external without any investment 
of time and/or finances. In this case, OI leads to resource exchange rather than bringing cost reduction.

\section{DISCUSSIONS AND CONCLUSIONS}

The purpose of this qualitative study was to contribute to literature on the Ol activities of university spin-offs by the interpretation of induction results rather than testing a specific hypothesis. While many research papers make claims about the openness of SMEs, and despite the growing popularity of the OI concept, our research demonstrates that not all SMEs know about $\mathrm{Ol}$, at least in Belgium. This is even more surprising for university spin-offs, which are assumed to be closer to advanced knowledge and practices. Consequently, such enterprises do not have a deliberately developed open or mixed innovation strategy. This fact can give additional food for thought and actions of business consultants and OI researchers.

At the same time, OI practice seems to be habitual for university spinoffs. To a certain extent, this fact supports the critics considering $\mathrm{Ol}$ as an old wine in new bottles. All interviewed spin-offs confirmed a current need in openness. However, not all of them tend to be more open. Indeed, despite the common view that spin-offs as enterprises are born to be naturally open or SMEs due to their small size are naturally open, some of them may chose a strategy towards a Close Innovation model in the later stages of development. In this case, the origin of the enterprise or its size do not serve any more as a key determinant of strategic choice. People working in the enterprises, with their own experience and knowledge, define the future Open or Closed Innovation practice of their firms. In this case, the decision to be more open or closed may depend on many other factors that include, but are not limited to, personal characteristics of managers (some personal experience, perceptions, ambitions and work style), industry, product under development, previous experience with Ol strategy, pressure of competition on the market and a lack of resources, and the stage of development of the firm.

Further, this research confirms previous studies which demonstrate that the experience of spin-offs is not limited by one model of innovation. Although the research focuses mostly on sourcing as a form of inbound innovation, the interviewed spin-offs use a mixed model of innovation where different types of Closed and Ol are used depending on specific objectives, available resources, and the type of expected results. At the same time, practice of OI remains somewhat unstructured. If the motives for adopting OI strategies are overcoming obstacles, the necessary step is to set up a coherent and formal strategy. Although traditional planning instruments, which take into account 
exploitation of internal technology and general information about markets, are in common among companies, there is a need to proliferate more specific planning instruments, concentrating on exploitation of external technology and innovations. This specific strategy is a focused, multiyear, business planning method that portrays the structural relationships, and needs to be fully integrated into a firm's strategic planning and business operations.

Also, current research on university spin-offs Ol practices, their motivations, benefits and disadvantages is conducted on relatively small number of observations. It does not allow generalization but rather points to important issues of $\mathrm{Ol}$ practice in university spin-offs such as a possible lack of knowledge about OI, a lack of structured formal practice and planning instruments, a variation of degree of openness and direction towards open or close model. More research, involving larger samples, would test current results more rigorously and extend the existing models. New benefits and costs could be also identified. More integrated theories and appeal for making fundamental changes to a company's business model are needed. Crossindustry comparisons are also limited in number and would considerably strengthen the current knowledge. All additional research would allow a better definition of OI practice in SMEs in general and university spin-offs in particular.

\section{Acknolwedgements}

I would like to take this opportunity to thank all those who contributed to this project. In particular, my thanks go to the whole of the project team Linkin' Wallonia (at the University of Liege) and to the representatives of the enterprises who kindly agreed to be interviewed. Without their contribution this project could not have been completed. I would also like to thank Dr. Andrey Martovoy, researcher and FinTech Adviser (ABBL), and the anonymous reviewers for their useful comments which allowed me to significantly improve this piece of work.

\section{References}

Arvanitis, S., Kubli, U., \& Woerter, M. (2008). University-industry knowledge and technology transfer in Switzerland: What university scientists think about co-operation with private enterprises. Research Policy, 37(10), 1865-1883.

Bianchi, M., Campodall'Orto, S., Frattini, F., \& Vercesi, P. (2010). Enabling open innovation in small- and medium-sized enterprises: How to find alternative applications for your technologies. $R \& D$ Management, 40(4), 414-431. 
Biondi, S., Calabrese, A., Capece, G., Costa, R., \& Di Pillo, F. (2013). A new approach for assessing dealership performance: An application for the automotive industry. International Journal of Engineering Business Management, 5, 1-8.

Brunswicker, S., \& Ehrenmann, F. (2013). Managing open innovation in SMEs: A good practice example of a german software firm. International Journal of Industrial Engineering and Management, 4(1), 33-41.

Chesbrough, H. (2003). Open Innovation: The New Imperative for Creating and Profiting from Technology. Boston, M.A.: Harvard Business Press.

Chesbrough, H. (2010). Business model innovation: Opportunities and barriers. Long Range Planning, 43(2-3), 354-363.

Chesbrough, H., Vanhaverbeke, W., \& West, J. (2006). Open Innovation: A New Paradigm for Understanding Industrial Innovation. In H. Chesbrough (Ed.), Open Innovation: Researching a New Paradigm. Oxford: Oxford University Press.

Chesbrough, H. W., \& Appleyard, M. M. (2007). Open innovation and strategy. California Management Review, 50(1), 57-76.

Druilhe, C., \& Garnsey, E. (2004). Do Academic Spin-Outs Differ and Does it Matter? The Journal of Technology Transfer, 29(3/4), 269-285.

Elmquist, M., Fredberg, T., \& Ollila, S. (2009). Exploring the field of open innovation. European Journal of Innovation Management, 12(3), 326345.

Gassmann, O., Enkel, E., \& Chesbrough, H. (2010). The future of open innovation. R\&D Management, 40(3), 213-221.

Gianiodis, P. T., Ellis, S. C., \& Secchi, E. (2010). Advancing A Typology Of Open Innovation. International Journal of Innovation Management.

Gunasekara, C. (2006). Reframing the Role of Universities in the Development of Regional Innovation Systems. The Journal of Technology Transfer, 31(1), 101-113.

Herzog, P. (2011). Open and Closed Innovation: Different Cultures for Different Strategies (2nd ed.). Wiesbaden: GABLER.

Huizingh, E. K. R. E. (2011). Open innovation: State of the art and future perspectives. Technovation, 31(1), 2-9.

Lee, S., Park, G., Yoon, B., \& Park, J. (2010). Open innovation in SMEs-An intermediated network model. Research Policy, 39(2), 290-300.

Lindegaard, S. (2010). The Open Innovation Revolution: Essentials, Roadblocks, and Leadership Skills. Hoboken, N.J.: Wiley.

Link, A. N., \& Scott, J. T. (2005). Opening the ivory tower's door: An analysis of the determinants of the formation of U.S. university spin-off companies. Research Policy, 34(7), 1106-1112.

Meyer-Krahmer, F., \& Schmoch, U. (1998). Science-based technologies: university-industry interactions in four fields. Research Policy, 27, 835851.

Miles, M. B., \& Huberman, M. A. (1994). Qualitative data analysis: An expanded sourcebook (2nd ed., Vol. 19). Thousand Oaks: SAGE Publications. 
Oakey, R. P. (2013). Open innovation and its relevance to industrial research and development: The case of high-technology small firms. International Small Business Journal, 31(3), 319-336.

Perkmann, M., \& Walsh, K. (2007). University-industry relationships and open innovation: Towards a research agenda. International Journal of Management Reviews, 9(4), 259-280.

Petroni, G., Venturini, K., \& Verbano, C. (2012). Open innovation and new issues in R\&D organization and personnel management. The International Journal of Human Resource Management, 23(1), 147-173.

Pirnay, F., Surlemont, B., \& Nlemvo, F. (2003). Toward a typology of university spin-offs. Small Business Economics, 21, 355-369.

Schartinger, D., Rammer, C., \& Fröhlich, J. (2006). Knowledge Interactions between Universities and Industry in Austria: Sectoral Patterns and Determinants. In: M. Fischer (Ed.), Innovation, Networks, and Knowledge Spillovers SE - 7 (pp. 135-166), Berlin-Heidelberg: Springer.

Shane, S. (2004). Academic entrepreneurship: University spinoffs and wealth creation. Cheltenham: Edward Elgar Publishing.

Sisodiya, S. R., Johnson, J. L., \& Grégoire, Y. (2013). Inbound open innovation for enhanced performance: Enablers and opportunities. Industrial Marketing Management, 42(5), 836-849.

Spithoven, A., Vanhaverbeke, W., \& Roijakkers, N. (2013). Open innovation practices in SMEs and large enterprises. Small Business Economics, 41(3), 537-562. http://doi.org/10.1007/s11187-012-9453-9

Steffensen, M., Rogers, E. M., \& Speakman, K. (2000). Spin-offs from research centers at a research university. Journal of Business Venturing, 15(1), 93-111.

van de Vrande, V., de Jong, J. P. J., Vanhaverbeke, W., \& de Rochemont, M. (2009). Open innovation in SMEs: Trends, motives and management challenges. Technovation, 29(6-7), 423-437.

van Geenhuizen, M., \& Soetanto, D. P. (2009). Academic spin-offs at different ages: A case study in search of key obstacles to growth. Technovation, 29(10), 671-681.

Van Geenhuizen, M., \& Soetanto, D. P. (2012). Benefitting from Learning Networks in "Open Innovation": Spin-off Firms in Contrasting City Regions. European Planning Studies, 21(5), 1-17.

Walter, A., Parboteeah, K. P., Riesenhuber, F., \& Hoegl, M. (2011). Championship Behaviors and Innovations Success: An Empirical Investigation of University Spin-Offs*. Journal of Product Innovation Management, 28(4), 586-598.

Wennberg, K., Wiklund, J., \& Wright, M. (2011). The effectiveness of university knowledge spillovers: Performance differences between university spinoffs and corporate spinoffs. Research Policy, 40(8), 1128-1143.

West, J., \& Gallagher, S. (2006). Challenges of open innovation: The paradox of firm investment in open-source software. $R \& D$ Management, 36(3), 319-331. 
West, J., Vanhaverbeke, W., \& Chesbrough, H. (2006). Open Innovation: A Research Agenda. In: H. Chesbrough (Ed.), Open Innovation: Researching a New Paradigm (pp. 1-15), Oxford: Oxford University Press.

Wikhamn, B. R. (2013). Two different perspectives on open innovation -libre versus control. Creativity and Innovation Management, 22(4), 375-389.

Wild, R., \& Griggs, K. (2008). A model of information technology opportunities for facilitating the practice of knowledge management. VINE, 38(4), 490506.

\section{Abstract (in Polish)}

Niniejszy artykuł analizuje praktykę otwartych modeli innowacji/Open Innovation (OI) w działalności uczelnianych spółek spin-off. Przeprowadzono trzy wywiady w celu omówienia wiedzy spótek spin-off o Ol, ich stosunku do tej strategii zarzqdzania innowacjami w oparciu o dostrzegane zalety $i$ wady, oraz ich motywacji do podejmowania praktyk Ol w przyszłości. Problemy planowania, kontroli i zaufania wydaja się być najważniejsze dla sukcesu Ol. Skupiajqc się na tych problemach $i$ innych ważnych aspektach Ol artykuł omawia programy badań, które moga pomóc w formułowaniu pytań badawczych i hipotez, tym samym ukierunkowujqc wysitki na poszukiwanie rozwiqzań zidentyfikowanych problemów.

Słowa kluczowe: innowacja, otwarta innowacja, spin-off, małe i średnie firmy.

\section{Biographical note}

Dr. Yuliya Shutyak has more than 10 years of analytical and research experience gained in European universities, NGOs, and business organizations as well as during her work as a consultant in SMEs and entrepreneurship. 